\title{
Effects of Inclusion Levels of Sweet Potato Vine Silage on Feed Intake, Milk Production and Profitability of Lactating Crossbred Dairy Cows
}

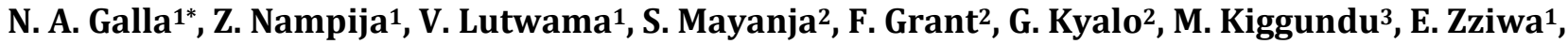 \\ J. Nambi-Kasozi ${ }^{1}$ \\ ${ }^{1}$ Makerere University, Kampala, Uganda \\ ${ }^{2}$ International Potato Center, Kampala, Uganda \\ ${ }^{3}$ National Livestock Resources Research Institute, Kampala, Uganda \\ Email: ^gnaabba@gmail.com
}

How to cite this paper: Galla, N.A., Nampija, Z., Lutwama, V., Mayanja, S., Grant, F., Kyalo, G., Kiggundu, M., Zziwa, E. and Nambi-Kasozi, J. (2020) Effects of Inclusion Levels of Sweet Potato Vine Silage on Feed Intake, Milk Production and Profitability of Lactating Crossbred Dairy Cows. Open Journal of Animal Sciences, 10, 608-617. https://doi.org/10.4236/ojas.2020.103039

Received: May 25, 2020

Accepted: July 21, 2020

Published: July 24, 2020

Copyright $\odot 2020$ by author(s) and Scientific Research Publishing Inc. This work is licensed under the Creative Commons Attribution International License (CC BY 4.0).

http://creativecommons.org/licenses/by/4.0/

\begin{abstract}
Feed scarcity is a major challenge in smallholder production systems especially during the dry season. Sweet potato vines (SPV) contribute over $40 \%$ of the crop residues fed to dairy cattle but they are highly perishable resulting into losses of about $24 \%$ per season. Ensiling SPV mitigates seasonal feed shortages and assists in coping with seasonal feed price fluctuations. This study was conducted to evaluate the effect of sweet potato vines silage (SPVS) supplementation on the performance of lactating Ankole $\times$ Friesian crossbred dairy cattle. Four primiparous cows in early lactation were randomly allotted a basal diet of Rhodes grass (Chloris gayana) hay supplemented with dairy pellets and four graded levels of SPVS (0, 100, 200 and $300 \mathrm{~g} / \mathrm{kg}$ of the daily ration) in a $4 \times 4$ Latin square design. The animals were given a one-week adaptation period followed by a two weeks data collection period for each diet. Dry matter intake (DMI), live weight changes, milk yield and composition were determined. Dry matter intake improved with addition of SPVS (P $\leq$ 0.05), with intake being highest $(11.9 \mathrm{~kg})$ in cows that were fed the highest SPVS level and lowest in cows that were not given SPVS $(6.8 \mathrm{~kg})$. Although animals on diets with $0,100,200 \mathrm{~g}$ of SPVS $/ \mathrm{kg}$ of daily ration lost weight, there were no significant differences $(\mathrm{P} \geq 0.05)$ in body weight changes across all treatments. Milk yield increased with SPVS supplementation by $1.5-1.7$ kg per cow per day but there were no significant differences between the different SPVS supplementation levels. Milk fat and solids-non-fat differed ( $\mathrm{P} \leq$ 0.05 ) across the four diets but there was no consistent trend observed. Considering profit margins, supplementing dairy cows with SPVS at a level of 100 $\mathrm{g} / \mathrm{kg}$ of daily ration was the most profitable at Uganda shillings $1290(0.344$
\end{abstract}


USD) per cow per day. In conclusion, SPVS supplementation improved DMI and milk yield but supplementation beyond $100 \mathrm{~g} / \mathrm{kg}$ of the daily feed intake was not cost-effective.

\section{Keywords}

Dry Matter Intake, Milk Composition, Rhodes Grass, Supplementation

\section{Introduction}

Under the Uganda Vision 2040 development framework, the Government of Uganda identified milk as one of the twelve agricultural commodities of focus for accelerated development of the agricultural sector. Uganda's dairy sector is therefore critical with high potential of improving food security and welfare. Feed is one of the critical resources that determine the potential for growth in the dairy sector. Smallholder dairy cattle production in Uganda however, largely depends on seasonal feed resources, which are relatively low in quantity and quality. Apart from Napier grass (Pennisetum purpureum) as the main forage source for urban and peri-urban dairy production, animals are also fed natural pastures, crop residues and agro-industrial by-products [1] [2].

Sweet potato is one of the most important food crops in Uganda producing large volumes of vines, which are left in the field after harvesting. These sweet potato vines can effectively be utilized as dairy cattle feed. The value of sweet potato vines is attributed to their inherent characteristics that include high levels of water-soluble carbohydrates, palatability, crude protein and high digestibility $(>62 \%)$ [3]. The crude protein content of sweet potato forage ranges from 180 to $300 \mathrm{~g} / \mathrm{kg}$ dry matter among different varieties, while the crude fiber content is about $180 \mathrm{~g} / \mathrm{kg}$ DM. Phesatcha and Wanapat [4] reported improved milk yield in Holstein crossbred cows fed pelleted sweet potato vines. Also, [5] indicated that ensiling sweet potato vines eliminates trypsin inhibitor leading to improved protein digestibility. In the rainy season, the vines are also available in plenty from peri-urban and urban food markets [6] [7] [8]. However, due to their high moisture content and bulkiness, a lot of the sweet potato vines cannot be kept for long because they rot and deteriorate in feeding value. To facilitate the use of sweet potato vines beyond the rainy season and to bridge the feed gap in the dry season, there is a need to conserve the sweet potato vines in form of silage. Traditionally, sweet potatoes can be grown two to three times per year giving large quantities of sweet potato vines that can be ensiled. There are no known studies in Uganda that have assessed the performance of crossbred dairy cattle fed sweet potato vine silage under smallholder dairy production systems. The purpose of this study therefore was to evaluate the effects of different inclusion levels of sweet potato vine silage on feed intake, milk production and profitability of lactating dairy cows. 


\section{Materials and Methods}

\section{Description of experimental site}

The study was conducted at Site Farm located in Nakyesasa village, Wakiso District about $24 \mathrm{~km}$ along the Kampala-Busiika road. Wakiso district $\left(0.0630^{\circ} \mathrm{N}, 32.4467^{\circ} \mathrm{E}\right)$ is located in the central region of Uganda and is bordered by Nakaseke and Luwero districts in the North, Mukono in the East, Kalangala in the South, Mityana in the Northwest and Mpigi district in the Southwest. Selection of the farmer was based on; willingness to participate in the study; allowing other farmers to visit the experimental site; having sweet potato as one of the major crops grown on the farm and having at least four early lactating primiparous Ankole $\times$ Friesian dairy cows.

\section{Experimental animals, diets and experimental design}

Four primiparous Ankole $\times$ Friesian crossbred dairy cows in early lactation with average milk yield of $9.21 \pm 1.68$ liters and average body weight of $422.92 \pm$ $26.15 \mathrm{~kg}$ were used in this study. The animals were housed in individual pens and treated against internal and external parasites before commencement of the experiment. Four diets were offered to the animals in a $4 \times 4$ Latin square change over design with four feeding periods each lasting 21 days. Animals were allowed a 7-day adaptation period before the start of data collection for every period. The basal diet consisted of Chloris gayana (Rhodes grass) hay offered ad $l i b$ and four kg of dairy pellets fed in two portions during morning and evening milking. Animals were then supplemented with SPVS at levels of 0, 100, 200 and $300 \mathrm{~g} / \mathrm{kg}$ of the total daily ration to constitute the four treatment diets (Table 1). To ensure that all the SPVS was consumed, it was offered first after the morning milking before providing Rhodes grass hay. Each of the diets were formulated to provide at least $12 \% \mathrm{CP}$ required for moderate levels of production [9]. The animals had free access to clean drinking water and commercial mineral block licks.

The daily feed intake was determined by subtracting the refused feed of a given day from the total feed offered that day. Feeds were sampled once during each feeding period and taken to the laboratory for chemical analyses. Milking was done twice a day at 05:00 hrs and at 16:00 hrs and the total daily yields were

Table 1. Feed composition of the experimental diets fed to the lactating dairy cows.

\begin{tabular}{ccccc}
\hline & Diets & \\
\hline & D0 & D100 & D200 & D300 \\
\hline $\begin{array}{c}\text { Component (kg/day) } \\
\text { Rhodes grass hay }\end{array}$ & 14 & 12 & 10 & 09 \\
Sweet potato vines & 0 & 06 & 12 & 18 \\
Dairy pellets & 4 & 4 & 4 & 4
\end{tabular}

*For Rhodes grass, the minimum amount that had to be consumed to meet the required CP intake is the quantity listed under each treatment. All animals had access to commercial mineral block licks (Percentage composition P 0.20, Ca 0.14, Mg 0.50, Fe 0.15, Co 0.005, Cu 0.03, I 0.015, Mn 0.02, Zn 0.03, Se 0.001 and Na 38). 
recorded. Milk samples were collected during the second week of data collection on each diet and taken to the laboratory to be analyzed for milk fat and total solids. The live body weights $(\mathrm{kg})$ of the animals on each treatment were determined using a heart girth tape and body weights were taken at the beginning of data collection and subtracted from the final weights at the end of each treatment to compute the live weight changes (average daily gains) of the animals on the different diets. The $4 \%$ fat corrected milk yield (FCM) was determined using the formula: $\mathrm{FCM}=0.4 M+15 F[10]$; where $M=$ weight of the milk and $F=$ the fat weight in the milk.

\section{Chemical analyses}

Samples of about $0.3 \mathrm{~kg}$ of Chloris gayana hay, SPVS and homemade dairy pellets were randomly picked and taken to the laboratory for chemical analysis. At the laboratory, they were weighed and oven dried at $60^{\circ} \mathrm{C}$ to constant weight for 48 hours in a forced draft oven and then ground through a $1 \mathrm{~mm}$ sieve pending chemical analysis. The dried samples were analyzed for crude protein (CP) using Kjeldahl method as described by [11]. Neutral Detergent Fiber (NDF) and Acid Detergent Fiber (ADF) were analyzed according to procedures outlined by [12], while in vitro organic matter digestibility (IVOMD) was determined using the [13] technique. Calcium (Ca) and Phosphorus (P) levels were determined using methods described by [14]. Metabolizable energy (ME) was estimated using a regression equation developed by [15] where ME (MJ/kg DM) $=0.15 \times$ IVOMD; and IVOMD $=$ in vitro organic matter digestibility $(\%)$.

\section{Statistical analysis}

The effects of the different levels of SPVS on feed intake, live weight, milk yield and composition were tested using Analysis of Variance (ANOVAs) of the General Linear Models Procedure (GLM) in [16] for a balanced $4 \times 4$ Latin square design using the model below:

$$
X_{i j k}=\mu+\alpha_{i}+\beta_{j}+\gamma_{k}+\varepsilon_{i j k} ; i, j \text { and } k=1 \cdots a
$$

where: $X_{i j k}=$ the $k$ th observation on the response variable under the th treatment.

$$
\begin{aligned}
& \mu=\text { Over all mean. } \\
& \alpha_{i}=\text { Treatment effect }(i=1 \ldots 4) . \\
& \beta_{j}=\text { Period effect }(j=1 \ldots 4) . \\
& \gamma_{k}=\text { Animal effect }(k=1 \ldots 4) . \\
& \varepsilon_{i j k}=\text { Random error effect. }
\end{aligned}
$$

Differences among treatment means were compared using Tukey's test of [16].

\section{Results}

The chemical composition of the different diet ingredients is presented in Table 2. Dry matter, NDF and ADF levels of the ingredients were highest in Rhodes grass hay (RGH). Among the supplements, sweet potato vine silage had higher $\mathrm{CP}$ and ash levels than the dairy pellets. The dairy pellets had the highest ME 
Table 2. Chemical composition ( $/ \mathrm{kg} \mathrm{DM})$ of the feeds used in feeding the lactating dairy cows.

\begin{tabular}{cccc}
\hline & RGH & SPVS & Dairy pellets \\
\hline Proximate Component & & & \\
Dry matter & 830 & 266 & 680 \\
Crude Protein & 75 & 194 & 148 \\
Neutral detergent fiber & 780 & 333 & 157 \\
Acid detergent fiber & 441 & 186 & 59 \\
Acid detergent lignin & 137 & 59 & 40 \\
Ash & 104 & 85 & 74 \\
Metabolisable Energy (MJ/kg DM) & 198 & 772 & 795 \\
\hline
\end{tabular}

RGH $=$ Rhodes grass hay, SPVS $=$ sweet potato vine silage.

while Rhodes grass had the lowest. As would be expected, the supplements had higher CP than Rhodes grass hay.

Dry matter intake and in vitro organic matter digestibility

There was a general DMI increase with increasing levels of SPVS supplementation (Table 3). Dry matter intake was lowest for the cows that received no SPVS and highest for the cows that received the highest level of SPVS supplementation. In vitro digestibility of the diets did not differ across the four levels of SPVS supplementation.

\section{Milk yield and composition \& economics of SPVS supplementation}

Daily milk yield increased with SPVS supplementation $(\mathrm{P} \leq 0.05)$ with no significant differences between the different levels of SPVS supplementation (Table 4). Fat corrected milk yield varied $(\mathrm{P} \leq 0.05)$ in a similar way as daily milk yield; being lowest in cows that did not receive SPVS supplementation. Considering the milk components, milk fat and solids-non-fat were affected $(\mathrm{P} \leq 0.05)$ by the different diets although the results did not show any consistent trend across the varying levels of SPVS supplementation. As would be expected, the cost of SPVS supplementation increased with increasing levels of SPVS in the diets (Table 5). Although there was increase in income due to the higher milk yield obtained from SPVS supplementation, profits were only realized at the $100 \mathrm{~g}$ of SPVS $/ \mathrm{kg}$ of daily ration.

\section{Discussion}

The CP level in SPVS of $194 \mathrm{~g} / \mathrm{kg}$ reported in this study is higher than CP levels reported elsewhere [17] [18] [19]. This could be attributed to differences in sweet potato varieties, vine parts [20] and the foliage to stem ratio at the time of ensiling [21]. The SPVS dry matter level of $226 \mathrm{~g} / \mathrm{kg}$ is within the range reported by [5]. The high CP and dry matter levels of SPVS reported in this study make SPVS a viable feed resource and supplement for diets with low digestibility and limiting crude protein as reported elsewhere by [22]. However, highly fermentable diets require the inclusion of adequate amounts of fiber to reduce the risk of 
Table 3. Dry matter intake and average daily gains of the lactating dairy cows fed the experimental diets.

\begin{tabular}{|c|c|c|c|c|c|}
\hline \multirow[b]{2}{*}{ Parameter } & \multicolumn{4}{|c|}{ Dietary treatment } & \multirow{2}{*}{ SEM } \\
\hline & Do & D100 & D200 & D300 & \\
\hline \multicolumn{6}{|l|}{$\mathrm{DM}$ intake, $\mathrm{Kg} /$ day } \\
\hline Dairy pellets & 2.7 & 2.7 & 2.7 & 2.7 & - \\
\hline Rhodes grass hay & 4.1 & 4.2 & 4.3 & 4.4 & 0.24 \\
\hline SPVS & 0.0 & 1.6 & 3.2 & 4.8 & - \\
\hline Total & $6.8^{\mathrm{d}}$ & $8.5^{\mathrm{c}}$ & $10.2^{\mathrm{b}}$ & $11.9^{\mathrm{a}}$ & 0.24 \\
\hline IVOMD (g/kg) & 442.1 & 510.4 & 549.6 & 566.0 & 13.9 \\
\hline Average final weights (Kg) & 414.8 & 415.4 & 418.9 & 432 & 4.87 \\
\hline Average daily gains ( $\mathrm{Kg} /$ day) & -0.20 & -0.25 & -0.22 & 0.35 & 0.06 \\
\hline
\end{tabular}

Diets D0, D100, D200 and D300 had sweet potato vine silage at 0, 100, 200 and $300 \mathrm{~g} / \mathrm{kg}$ respectively. ${ }_{a, b, c, d}$ Means within a row with different superscripts differ significantly $(P \leq 0.05)$. SEM = Standard error of the mean.

Table 4. Effects of sweet potato vine silage on milk yield and composition of the lactating dairy cows.

\begin{tabular}{|c|c|c|c|c|c|c|}
\hline & \multicolumn{4}{|c|}{ Dietary treatments } & \multirow{2}{*}{ SEM } & \multirow{2}{*}{$\mathrm{p}$-value } \\
\hline & Do & D100 & D200 & D300 & & \\
\hline \multicolumn{7}{|l|}{ Production } \\
\hline Milk yield, $\mathrm{Kg}$ /day & $8.3^{\mathrm{b}}$ & $10.0^{\mathrm{a}}$ & $9.8^{\mathrm{a}}$ & $9.9^{\mathrm{a}}$ & 0.26 & 0.01 \\
\hline Fat corrected milk, $\mathrm{Kg} /$ day & $9.21^{\mathrm{b}}$ & $10.21^{\mathrm{a}}$ & $10.76^{\mathrm{a}}$ & $10.82^{\mathrm{a}}$ & 0.28 & 0.01 \\
\hline \multicolumn{7}{|l|}{ Milk composition (\%) } \\
\hline Butter fat & $4.7^{\mathrm{a}}$ & $4.1^{\mathrm{b}}$ & $4.7^{\mathrm{a}}$ & $4.6^{\mathrm{ab}}$ & 0.14 & 0.05 \\
\hline Solids-not-fat & $8.2^{\mathrm{b}}$ & $8.6^{\mathrm{a}}$ & $8.2^{\mathrm{b}}$ & $8.2^{\mathrm{b}}$ & 0.06 & 0.01 \\
\hline Total solids & 12.9 & 12.8 & 12.9 & 12.8 & 0.10 & 0.86 \\
\hline
\end{tabular}

Diets D0, D100, D200 and D300 had sweet potato vine silage at 0, 100, 200 and $300 \mathrm{~g} / \mathrm{kg} \cdot{ }^{\mathrm{a}, \mathrm{b}, \mathrm{c}} \mathrm{Means}$ within a row with different superscripts differ significantly $(\mathrm{P} \leq 0.05)$. SEM $=$ Standard error of the mean.

Table 5. Economics of supplementing dairy cows with varying levels of sweet potato vine silage.

\begin{tabular}{ccccc}
\hline Diets & Cost (Ugx) & Increase in milk yield (Liters) & Additional income (Ugx) & Profit (Ugx) \\
\hline D0 & 0 & 0 & 0 & 0 \\
D100 & 1410 & 1.8 & 2700 & 1290 \\
D200 & 2820 & 1.5 & 2250 & -570 \\
D300 & 4230 & 1.6 & 2400 & -1830 \\
\hline
\end{tabular}

The cost of producing SPVS was Ugx 235 per kg and the price of milk was Ugx 1500 per liter, 1 USD $=3750$ Ugx.

sub-acute rumen acidosis. Such measures enable effective utilization of agricultural by-products such as sweet potato vines. The DMI increase with increase in 
quantity of SPVS supplementation observed in this study is in agreement with an earlier study conducted by [23] in goats. Dry matter intake and digestibility depend on fermentability of the energy source. When supplements supply all the necessary nutrients to microbes especially nitrogen which is usually the most limiting nutrient, the microbial population will increase and ferment feed at a faster rate thereby creating space for more feed intake. The lower level of neutral detergent fiber in SPVS compared to that in Rhodes grass hay also led to their effective degradation hence the better feed intake for cows that received SPVS supplementation. High levels of neutral detergent fibre in feeds limit their intake. Although diets based on by-products usually contain lower amounts of degradable starch, they might be rich in other nutrients, such as cell wall soluble components, rumen undegradable protein and potentially digestible fiber [24]. The improved dry matter intake of the cows that received SPVS subsequently led to the observed increased milk yield.

Though dry matter intake increased with increasing levels of SPVS supplementation, there was noticeable loss of body weight for cows at 0,100 and 200 $\mathrm{g} / \mathrm{kg}$ of SPVS supplementation. This could be explained by the general body weight loss that usually occurs in the first phase (4 months after parturition) of lactation in primiparous cattle [25]. The animals usually lose weight as they mobilize body reserves possibly due to a negative energy balance to produce milk and/or due to increasing levels of milk yield [26].

Milk yield was higher and similar in cows that were fed the different SPVS supplementation levels. The findings are in agreement to those observed by [17], and [4]. This was due to increased DMI hence more nutrient ingestion and nitrogen utilization with SPVS supplementation [3]. Fat corrected milk content improved with SPVS supplementation though there was no consistent trend across the four levels of SPVS supplementation. The increased fat corrected milk is most likely a result of increasing levels of fibrous material with increased DMI in the diets known to balance the acetate to propionate ratio in the rumen liquor as acetate is a major milk fat precursor [27].

Supplementing dairy cows with $100 \mathrm{~g}$ of SPVS per kilogram of daily ration yielded profit of Uganda shillings 1290 with non-significant levels of increase in milk yield beyond the $100 \mathrm{~g}$ of SPVS / $\mathrm{kg}$ of daily ration. Every additional unit of SPVS supplementation increased the unit cost of producing milk which did not offset changes in revenue from milk sales.

\section{Conclusion}

Supplementing dairy cattle with SPVS increased DMI and milk yield. Sweet potato vine silage is therefore a valuable feed resource that can lead to improved animal performance and better farm incomes. The findings of this study are in tandem with Uganda's vision 2040 to increase household income and reduce poverty. Under the conditions of this study, it was most profitable to supplement with $100 \mathrm{~g}$ of SPVS/kg of daily ration as higher inclusion levels translated into 
negative profits due to the high cost of producing SPVS. Famers need to be sensitized on cheaper ways of producing SPVS to increase profits accruing from its incorporation into animal diets.

\section{Acknowledgements}

The authors greatly acknowledge the financial support by CGIAR Research Program on Roots, Tubers and Bananas (RTB) and UKAID.

\section{Conflicts of Interest}

The authors declare no conflicts of interest regarding the publication of this paper.

\section{References}

[1] Lukuyu, B.A., Kitalyi, A., Franzel, S., Duncan, A. and Baltenweck, I. (2009) Constraints and Options to Enhancing Production of High Quality Feeds in Dairy Production in Kenya, Uganda and Rwanda. ICRAF Working Paper No. 95, World Agroforestry Centre, Nairobi, Kenya.

[2] Mugerwa, S., Kabirizi, J.M., Nanyenya, W., Matovu, M., Komutunga, E., Mubiru, D.N., Agona, A. and Zziwa, E. (2013) Simulation of Methane Emissions from Stall Fed Dairyanimals under Different Dietary Strategies in Uganda. Frontiers in Science, 3, 1-5.

[3] Ali, A.I.M., Wassie, S.E., Korir, D., Merbold, L., Goopy, J.P., Butterbach-Bahl, K., et al. (2019) Supplementing Tropical Cattle for Improved Nutrient Utilization and Reduced Enteric Methane Emissions. Animals, 9, 210.

[4] Phesatcha, K. and Wanapat, M. (2012) Performance of Lactating Dairy Cows Fed a Diet Basedon Treated Rice Straw and Supplemented with Pelleted Sweet Potato Vines. Tropical Animal Health and Production, 45, 533-538. https://doi.org/10.1007/s11250-012-0255-5

[5] Murugan, S., Paramasivam, S.K. and Nedunchezhiyan, M. (2012) Sweet Potato as Animal Feed and Fodder. Fruit, Vegetable and Cereal Science and Biotechnology, 6, Article ID: 106114.

[6] Katongole, C.B., Bareeba, F.B., Sabiiti, E.N. and Ledin, I. (2008) Nutritional Characterization of Some Tropical Urban Market Crop Wastes. Animal Feed Science and Technology, 142, 275-291. https://doi.org/10.1016/j.anifeedsci.2007.09.002

[7] Katongole, C.B., Sabiiti, E., Bareeba, F. and Ledin, I. (2011) Utilization of Market Crop Wastes as Animal Feed in Urban and Peri-Urban Livestock Production in Uganda. Journal of Sustainable Agriculture, 35, 329-342. https://doi.org/10.1080/10440046.2011.554318

[8] Kabirizi, J.M., Lule, P., Kyalo, G., Mayanja, S., Ojakol, J.F., Mutetikka, D., et al. (2017) Sweetpotato Silage Manual for Smallholder Farmers. Expanding Utilization of Roots, Tubers and Bananas and Reducing Their Postharvest Losses. Kampala (Uganda). CGIAR RTB. 24 p.

[9] ARC (1990) The Agricultural Research Council. Agricultural Research Council. http://www.arc.agric.za/

[10] Maynard, L.A., Loosli, J.K., Hintz, H.F. and Warner, R.G. (1979) Animal Nutrition. 7th Edition, McGraw-Hill, New York.

[11] AOAC. (Association of official Analytical Chemists) (1990) Official Methods of 
Analysis. 15th Edition, AOAC Inc., Arlington.

[12] Van Soest, P.J., Robertson, J.B. and Lewis, B.A. (1991) Methods for Dietary Fiber, Neutral Detergent Fiber, and Nonstarch Polysaccharides in Relation to Animal Nutrition. Journal of Dairy Science, 74, 3583-3597. https://doi.org/10.3168/jds.S0022-0302(91)78551-2

[13] Tilley, J.M.A. and Terry, R.A. (1963) A Two-Stage Technique for the in Vitro Digestion of Forage Crops. Grass Forage Science, 18, 104-111. https://doi.org/10.1111/j.1365-2494.1963.tb00335.x

[14] Okalebo, J.R., Gathua, K.W. and Woomer, P.L. (2002) Laboratory Methods of Soil and Plant Analysis: A Working Manual. 2nd Edition, Sacred Africa, Nairobi, 21.

[15] Close, W.H. and Menke, K.H. (1986) Selected Topics in Animal Nutrition Universitat. Hohenheim, 170, 85.

[16] Statistical Analysis System (2001) User's Guide, Version 8.2. SAS Institute, NC, USA.

[17] Khalid, A., Elamin, K., Amin, A., Eldar, A., Mohamed, M., Hassan, H., et al. (2013) Effect of Feeding Sweet Potato (Ipomoea batatas) Vines Silage on Performance and Milk Production of Nubian Goats. Journal of Animal and Veterinary Advances, 3, 153-159.

[18] Negesse, T., Gebremichael, G. and Beyan, M. (2016) Supplementary Effect of Sweet Potato (Ipomoea batatas) Silage on Growth Performance and Carcass Traits of Local Lambs Grazing Natural Pasture in Tembaro District, Southern Ethiopia. International Journal of Environment, Agriculture and Biotechnology, 1, 457-465. https://doi.org/10.22161/ijaers/3.10.23

[19] Lutwama, V., Gumisiriza, M., Dr. Kabirizi, J., Nampijja, J. and Kiggundu, M. (2016) Evaluation of Nutritional Quality of Silage from Sweet Potato Vines, Napier Grass and Their Mixtures as Feed for Livestock. International Journal of Agricultural and Environmental Research, 2, 1696-1708.

[20] Aregheore, E.M. (2004) Nutritive Value of Sweet Potato (Ipomea batatas (L) Lam) Forage as Goat Feed: Voluntary Intake, Growth and Digestibility of Mixed Rations of Sweet Potato and Batiki Grass (Ischaemum aristatum var. indicum). Small Ruminant Research, 51, 235-241. https://doi.org/10.1016/S0921-4488(03)00198-6

[21] Zereu, G., Negesse, T. and Nurfeta, A. (2014) Chemical Composition and in Vitro Dry Matter Digestibility of Vines and Roots of Four Sweet Potato (Ipomoea batatas) Varieties Grown in Southern Ethiopia. Tropical and Subtropical Agroecosystems, 17, 547-555.

[22] Nambi-Kasozi, J., Sabiiti, E.N., Bareeba, F.B., Sporndly, E. and Kabi, F. (2016) Effects of Inclusion Levels of Banana (Musa spp.) Peelings on Feed Degradability and Rumen Environment of Cattle Fed Basal Elephant Grass. Tropical Animal Health and Production, 48, 693-698. https://doi.org/10.1007/s11250-016-0999-4

[23] Megersa, T., Urge, M. and Nurfeta, A. (2012) Effects of Feeding Sweet Potato (Ipomoea batatas) Vines as a Supplement on Feed Intake, Growth Performance, Digestibility and Carcass Characteristics of Sidama Goats Fed a Basal Diet of Natural Grass Hay. Tropical Animal Health and Production, 45, 593-601. https://doi.org/10.1007/s11250-012-0264-4

[24] Hall, M.B. and Herejk, C. (2001) Differences in Yields of Microbial Crude Protein from in Vitro Fermentation of Carbohydrates. Journal of Dairy Science, 84, 2486-2493. https://doi.org/10.3168/jds.S0022-0302(01)74699-1

[25] Gross, J., Van Dorland, H.A., Bruckmaier, R.M. and Schwarz, F.J. (2011) Performance and Metabolic Profile of Dairy Cows During a Lactational and Deliberately 
Induced Negative Energy Balance with Subsequent Realimentation. Journal of Dairy Science, 94, 1820-1830. https://doi.org/10.3168/jds.2010-3707

[26] Poncheki, J.K., Canha, M.L.S., Viechnieski, S.L. and De Almeida, R. (2015) Analysis of Daily Body Weight of Dairy Cows in Early Lactation and Associations with Productive and Reproductive Performance. Revista Brasileira de Zootecnia Revista Brasileira de Zootecnia, 44, 187-192.

https://doi.org/10.1590/S1806-92902015000500004

[27] Lu, C.D., Kawas, J.R. and Mahgoub, O.G. (2005) Fibre Digestion and Utilization in Goats. Small Ruminant Research, 60, 45-52.

https://doi.org/10.1016/j.smallrumres.2005.06.035 